\title{
Overview of inflammatory bowel disease pathogenesis
}

\author{
C FIOCCHI
}

ABSTRACT: Inflammatory bowel disease (IBD) represents a difficult and challenging condition for patients, clinicians and basic investigators alike. Its etiology and pathogenesis are still unclear in spite of extensive investigations that have yielded a wealth of clinical, epidemiological, biochemical, bacteriological and immunological data on Crohn's disease and ulcerative colitis. Although the precise mechanism(s) responsible for the intestinal inflammatory process remain to be defined, enough information has been assembled to hypothesize which components are likely to be important for this probably multifactorial disease. A consistent association between class I or II histocompatibility antigens and either Crohn's disease or ulcerative colitis has yet to be found. Nevertheless, ample epidemiological studies leave no doubt about the high frequency of familial clustering, and it must be determined whether this phenomenon translates a true genetic predisposition or a common environmental exposure, or both. Immune events occurring in the gastrointestinal tract are unquestionably linked to the pathogenesis of IBD, but it is unknown which are primary or secondary in nature. While most immune abnormalities detected in prtients with established disease are likely to represent secondary events, these are no less important, as they probably contribute to the perpetuation of gut inflammation and tissue damage. This does not exclude that IBD is due to a primary defect of intestinal immunity, but this may no longer be detectable at the time of clinical manifestations. The answer to the question of which of the various intestinal immune abnormalities is central to pathogenesis must wait for additional research. Whether immune responses to the luminal flora, antigen processing mechanisms, antibody production, immunoregulation, cytotoxic activity, cytokine and mediator release are defective or disregulated is under intense investigation. It is likely that several of these events are involved, but they may interact in a complex and unpredictable fashion. It is almost certain that there are various initiating and secondary events, and different immune mechanisms share relatively few common pathways for damaging the intestine, eg, cytokines, arachidonic acid metabolites, and oxidants. Perseverance in the study of these substances is finally yielding promising new approaches to the manipulation of immune and inflammatory responses that cause bowel destruction. Future drugs may consist of combinations of highly specific inhibitors, antagonists or receptor blockers, that may selectively block one or several steps of the inflammatory cascade which is chronically active in the intestine of affected individuals. Therefore, we may soon face a situation not too dissimilar from what we have recently witnessed for peptic ulcer disease. The specific cause of IBD may still be beyond our comprehension, but a better understanding of its pathogenesis allows us to put highly effective therapies within reach. Can J Gastroenterol 1990;4(7):309-318 (pour résumé, voir page 310)

Key Words:Crohn's disease, Inflammatory bowel disease, Pathogenesis, Ulcerative colitis

Department of Gastroenterology, Cleveland Clinic Foundation, Cleveland, Ohio

Correspondence and reprints: Dr Fiocchi, Department of Gastroenterology, Cleveland Clinic Foundation, One Clinic Court, 9500 Euclid Avenue, Cleveland, OH 44195-5014, USA.

Telephone (216) 444-5373, Fax (216) 444-9329
A NY ATTEMPT TO DISCUSS, MUCH less define, the pathogenesis of inflammatory bowel disease (IBD) is a formidable and challenging task. Indeed, too many questions about the cause and mechanisms of IBD go presently unanswered. As a consequence, trying to establish definitively how this entity comes about, and why it persists chronically in the gastrointestinal tract of a sizeable portion of the world's population, appears to be beyond present capabilities and constitutes a major scientific problem. Although both Crohn's disease and ulcerative colitis, two generally well defined and distinct clinical entities, share the denomination of IBD, IBD is commonly referred to and thought of as a single entity. This erroneous concept derives from the numerous clinical, epidemiological, pathological and therapeutic similarities between Crohn's disease and ulcerative colitis, but also from ignorance about these two diseases. As a matter of fact it is not even certain whether either one is a single entity, or whether each one represents an umbrella which covers a variety of other disorders with shared protean clinical manifestations (1). This is particularly true for Crohn's disease; the possibility that it may represent a syndrome rather than a distinct illness has recently become the focus of attention (2). Even assuming that Crohn's disease and ulcerative colitis are clearly separable entities, it is unknown whether either is caused by one or more agents, and whether single or multiple pathogenetic events are implicated in triggering and perpetuating the mechanism(s) of intestinal tissue injury. 


\section{Pathogenèse des maladies inflammatoires de l'intestin}

RESUME: Les maladies inflammatoires de l'intestin posent des problèmes difficiles au patient, au clinicien et au chercheur. Leurs causes et pathogenèse sont peu claires malgré les recherches étendues et la mine de données cliniques, épidémiologiques, biochimiques, bactériologiques et immunologiques recueillies sur la maladie de Crohn et la colite ulcéreuse. Bien que les mécanismes précis du processus inflammatoire soient à définir, les données sont suffisantes pour autoriser la formulation d'hypothèses. Il nous reste encore à trouver une association constante entre les antigènes d'histocompatibilité de classe I ou II et la maladie de Crohn ou la colite ulcéreuse. Par contre, des études épidémiologiques étendues ne font aucun doute quant à la fréquence élevée du caractère familial de ces affections. Il reste donc à déterminer s'il s'agit d'une veritable prédisposition génétique ou de l'exposition à un environnement commun, ou les deux. Il est indéniable que les réponses immunitaires qui surviennent dans les vaoies gastrointestinales sont liées à la pathogenèse des MIl, mais on ne sait pas ce qui survient en premier et en second. Si la plupart des anomalies décelées chez les cas diagnostiqués représentent en général des événements secondaires, elles n'en sont pas moins importantes et contribuent probablement à prolonger l'inflammation de l'intestin et les lésions tissulaires. Il n'est pourtant pas exclu que les MII résultent principalement de troubles immunitaires au niveau de l'intestin, lesquels ne seraient pas décelables au moment des manifestations cliniques. Il faut poursuivre les recherches pour déterminer laquelle des diverses anomalies immunitaires est essentiellement responsable des MII - réponses immunes à la flore des lumières, mécanisme de traitement des antigènes, production d'antigènes, immunorégulation, activité cytotoxique, libération des cytokines et des médiateurs. Tous ces phénomènes font l'objet d'études intenses. Il est probable que plusieurs d'entre eux soient impliqués mais ils pourraient interagir de façon complexe et imprévisible. Il est presque certain qu'il existe divers événements primaires et secondaires et que des mécanismes immunitaires différents empruntent un certain nombre de voies communes pour endommager l'intestin - cytokines, métabolites de l'acide arachidonique et oxydants. La persévérance des chercheurs ouvre finalement des voies prometteurses quant à la manipulation des réponses immunes et inflammatoires qui lèsent l'intestin. Les médicaments futurs allieront probablement plusieurs agents hautement spécifiques: inhibiteurs, antagonistes et bloquants des récepteurs, en mesure d'arrêter sélectivement une ou plusieurs étapes de la cascade inflammatoire qui est chroniquement à l'oeuvre dans l'intestin des personnes atteintes. Nous vivrons donc peut-être bientôt une situation similaire à celle de l'ulcère gastroduodénal; la cause précise des MII nous échappe encore mais une meilleure compréhension de sa pathogenèse met à notre portée des traitements particulièrement efficace

\section{POSSIBLE PATHOGENIC COMPONENTS IN IBD}

In spite of this confusing situation, a careful and objective analysis of the knowledge accumulated during the past two decades has narrowed the spectrum of causes and mechanisms that are likely to have direct or indirect relevance to the pathogenesis of IBD. As a result, it is now generally assumed that a variety of stimuli can trigger in susceptible individuals an immune response that will ultimately result in the local (intestinal) inflammatory reaction responsible for the clinical and pathological manifestations which lead to the diagnosis of Crohn's disease or ulcerative colitis. A series of possible pathogenic components are listed in Table 1 , and because it is presently impossible to single out any one of them as the definite cause of IBD, each deserves to be considered.

Infectious agents: Since the very beginning of the investigation of the cause of IBD, infectious agents have been considered prime causative candidates, mostly due to the similarities of ulcerative colitis to colitides of proved infectious etiology, such as shigellosis, salmonellosis, etc. Over the years, a large number of microbiological agents
TABLE 1

Possible pathogenic components in inflammatory bowel disease

\begin{tabular}{l} 
Infectious agents \\
Immunogenetics \\
Autoimmunity \\
Abnormal immune response \\
Psychoneuroimmunology \\
\hline
\end{tabular}

has been proposed as possible culprits. Common as well as unusual bacteria have enjoyed various degrees of popularity, invariably to be dismissed later as irrelevant or contaminating agents $(3,4)$. Later, the so-called 'transmissible agents' became the focus of attention, based on evidence of repetitive induction of granuloma formation in mouse footpads (5), cytopathic effect in tissue culture (6), and lymphomas in nude mice (7). All have been found later to be nonspecific and due to nonreplicating toxic substances $(8-10)$. Mycobacteria, which have long been considered a possible cause for Crohn's disease because of the presence of granulomatous inflammation in the gut, have had a recent resurgence in popularity (11).

A considerable amount of data have been generated rather rapidly, using classical microbiological as well as state-of-the-art molecular biological techniques (Table 2). Results have shown and concurred that Mycobacterium paratuberculosis can be recovered from the inflamed tissue of some patients with Crohn's disease. Nevertheless, when critically analyzed, the bulk of evidence fails to make a strong case for the etiological relevance of this microorganism to Crohn's disease. The frequency of recovery of $M$ paratuberculosis from involved bowel tissue is low (12), and other types of mycobacteria have also been isolated (13). Careful immunohistochemical analysis of Crohn's disease intestine has failed to reveal any evidence for the presence of acid-fast bacteria (14), and bowel ex. tracts do not hybridize with mycobac. terial genomic DNA probes from Crohn's disease tissue-isolated myco. bacteria (15). In addition, there is no significant elevation of antibody titres in the sera of Crohn's disease patients (16), who also display no evidence for 
an enhanced or decreased cellmediated immunity to mycobacterial antigens (17). Finally, preliminary studies do not show an elevation serum antibody titres to the mycobacterial cross-reacting heat shock proteins (HSP65) (unpublished data), and there is no evidence for an increase of gamma/ delta $T$ cell receptor-positive (TCR1) cells in intestinal lesions of Crohn's disease (18) (personal communication), as might be expected in an active mycobacteria infection (19). Therefore, in spite of the homology and immunological cross-reactivity between mycobacterial and human heat shock proteins (20), and the postulated role of these stress proteins in inflam. mation (21), the probability that some type of mycobacteria is responsible for Crohn's disease is inadequately substantiated.

Even though a specific bacterial, viral or fungal agent has yet to be identified, the role of microorganisms, and in particular the intestinal bacterial flora in the pathogenesis of IBD cannot be dismissed. The simple presence of a massive amount of antigens and mitogens of bacterial origin in the gut lumen must be taken into account because of its unquestionable impact on the local immune system and intrinsic inflammatory properties (Table 3 ). Endotoxin, a component of the cell wall of Gram-negative bacteria, is one of the most potent immunomodulatory substances (22). Enterobacterial common antigen is present in all enterobacteriaceae and cross-reacts with intestinal epithelial cells (23), and an enhanced humoral and cellular immune response to this antigen is detected in IBD patients $(24,25)$. Peptidoglycans from Gram-positive bacterial cell wall can cause subacute inflammation when injected in to the bowel wall (26), and intraluminal administration of the bacterial chemotactic peptide formyl-methionyl-leucylphenylalanine can induce colitis in experimental animals (27). A variety of additional products from the gut flora may exist with similar properties. At present it is impossible to determine what the exact role might be for these potent immunomodulatory and pro-

\section{TABLE 2}

\section{Evidence for mycobacterial involvement in Crohn's disease}

\begin{tabular}{ll}
\hline Direct & Indirect \\
\hline Infrequent recovery from involved bowel & $\begin{array}{c}\text { No significantly elevated serum } \\
\text { antibody titres } \\
\text { No significantly elevated/decreased } \\
\text { cell-mediated immune response }\end{array}$ \\
$\begin{array}{cc}\text { Negative immunohistochemical staining } \\
\text { in tissue }\end{array}$ & $\begin{array}{c}\text { No increase in serum antibody titres to } \\
\text { heat shock proteins (HSP65) } \\
\text { Negative DNA hybridization with tissue } \\
\text { extracts }\end{array}$ \\
$\begin{array}{c}\text { No increase of intestinal } \gamma / \delta \text { T cell } \\
\text { receptor cells }\end{array}$ \\
\hline
\end{tabular}

inflammatory agents in the pathogenesis of IBD, but it is likely that in some way they participate in the maintenance of gut inflammation.

Immunogenetics: The occurrence of familial aggregation in IBD has been recognized for several years (28). Several studies have confirmed this ob. servation, including the progressively high frequency, detected with prolonged follow-up (29). The problem with this well documented phenomenon is its interpretation, and two major theories have been proposed: the first is that it reflects a true genetic predisposition, and the second is that it is due to exposure to a common environmental agent(s). Unfortunately these two hypotheses have proved very difficult to confirm or dismiss, since all major studies have been unable to separate one factor clearly from the other (30). With the continuous advance of immunogenetics, and the increasingly common association of discrete disease entities with a particular genetic marker, a link of IBD to class I or class II major histocompatibility antigens has been vigorously pursued. With a few exceptions, like the linkage of the DR2 antigen to ulcerative colitis in Japanese patients (31), the search for a consistent and reproducible association of either Crohn's disease or ulcerative colitis with any particular human lymphocyte antigen (HLA) - A, B, C (class I) or HLA-DR, DP, DQ (class II) antigen has proven largely unproductive. Recent claims for a strong association of ulcerative colitis with a polymorphic $T$ cell receptor alpha-chain fragment (32) have not been confirmed (33). At present the search for IBD-associated genes continues, including not only those regulating the HLA region, but also those for the $T$ cell receptor, immunoglobulin allotypes and complement components.

Autoimmunity: Autoimmunity always represented an appealing mechanism to explain clinical and pathological manifestations in many diseases of chronic nature and unknown etiology. This is certainly the case with IBD, but it has been very difficult to pinpoint any single autoimmune phenomenon which is specific and reproducible for Crohn's disease or ulcerative colitis, and which may represent an initiating event for intestinal tissue damage (34). A hypothesis that presently enjoys much popularity among clinical immunologists is that of 'molecular mimicry' associated with a 'hit-and-run event' (35). In this concept, a primary agent, such as a virus, a bacterium or a foreign protein may attack a specific organ, triggering a local immune response, directed against the aggressor. This noxious offender may be eliminated or destroyed, but in doing so the immune system is forced to produce antibodies or generate cells sensitized to some of the offender's antigens which share the same molecular configuration with substances of the host's tissues (molecular mimicry). As a consequence, the immune system is now able to recognize and attack normal cells,

\section{TABLE 3}

\section{Potential role for intestinal bacterial} flora in inflammatory bowel disease

Specific microorganism?

Endotoxin (lipopolysaccharide)

Enterobacterial common antigen

Peptidoglycans

Formyl-methionyl-leucyl-phenylalanine Other bacterial products? 


\begin{tabular}{l} 
TABLE 4 \\
Possible targets of autoimmune \\
phenomena in inflammatory bowel \\
disease \\
\hline Fecal contents \\
Bowel extracts \\
Enterobacterial common antigen \\
(ECA/HSP60) \\
Epithelial cell-associated components \\
Mr 40,000 colonic protein \\
Heat shock proteins \\
(mycobacterial HSP65) \\
Neutrophils (antineutrophil cytoplasmic \\
antibodies)
\end{tabular}

triggering an autoaggressive reaction even though the initial culprit has completely disappeared (hit-and-run event). This theory has been suggested to explain some diseases such as glutensensitive enteropathy, ankylosing spondylitis and Reiter's syndrome, based on evidence of molecular mimicry of the wheat protein A-gliadin with the E1B protein of the human adenovirus $\mathrm{Ad}-12$ for celiac disease (36), and the HLAB27 allele with Klebsiella pneumoniae nitrogenase for the mentioned arthropathies (37).

If a similar mechanism exists in IBD, then the task of the investigators would be that of discovering which primary agent may trigger an immune response against what intestinal tissue or cell. However, not only do we not know what agent may have triggered an autoimmune response, but we are also not sure what the target of such a response is in spite of many having been proposed (Table 4). Fecal and bowel extracts have been used in the initial studies, but the crudeness of these preparations and the variability and inconsistency of results make the reported results difficult to evaluate (38). The presence of immunity to enterobacterial common antigen has already been mentioned, but this is not specific for IBD (39). The isolation of purified and well characterized intestinal antigens has added more scientific credibility to the investigation of autoimmune phenomena in IBD. The detection of intestinal mucosal $\mathrm{T}$ cells reactive against gut-specific epithelial cell-associated components lends some support to the existence of cytotoxic cells aimed at intestinal cells (40).
Similarly, the isolation of IgG tissuebound antibodies in ulcerative colitis directed towards a unique colonic antigen ( $\mathrm{Mr}$ 40,000 protein) speaks in favour of a specific form of autoimmunity in at least one form of IBD. Additional support for the potential value of this colonic autoantigen has been provided recently by the demonstration that the expression of $\mathrm{Mr}$ 40,000 is restricted to the colon, biliary tree and skin, locations which perfectly match the sites of clinical manifestations of ulcerative colitis (41). A recent report describing a new type of antineutrophil cytoplasmic antibody in ulcerative colitis (42), and the already mentioned sharing of biochemical and immunological characteristics between heat shock proteins and bacterial stress proteins (20), further increase the need to investigate these novel findings and study their relevance to autoimmune events in IBD. By the time of obvious clinical signs and symptoms of IBD, it may be impossible to recognize an earlier autoimmune response, but this does not diminish the importance of subsequent autoimmune reactions that may be critical in explaining the relapsing nature of intestinal inflammation.

Abnormal immune response: The participation of the immune system in the pathogenesis of chronic inflammatory diseases is not restricted to autoimmune responses, in which a functional immune system incorrectly interprets the host's antigens as foreign substances. The immune system itself may be intrinsically abnormal and mount a defective or inappropriate response against an appropriate target. Due to the complexity of the immune system and the multiplicity of its cellular and soluble components, the potential for a defective step can reside at the level of any of a myriad of cells, antibodies and cytokines. The purpose of this discussion is not to review all reported anomalies of systemic and intestinal immunity in IBD, since excellent references are available (43). Rather, it is appropriate to stress the unquestionable role that intestinal immunity plays in mediating the inflammatory process of Crohn's disease and ulcerative colitis (44). A variety of findings have been reported, including abnormalities of $\mathrm{T}$ cell activation, antibody production, cytokine activities, complement activation, etc $(40,45-49)$. On one end a major challenge facing the investigators of IBD is to try to separate primary from secondary mucosal immune abnormalities. On the other end, as discussed for autoimmunity, this challenge would be a trivial point, as different immune events are probably important at different stages of the disease. Indeed, most of them could be implicated as mediators of tissue injury, as will be discussed later.

Psychoneuroimmunology: Clinical observations have long called attention to the intriguing relationship between stressful events of life and the beginning of Crohn's disease or ulcerative colitis, and the modulation of the clinical course of IBD by social factors. After the transient trend of purely psychosomatic theories, scientific support for a demonstrable physical link between the environment and the different organs of the body has been found in combined studies of the neuroendocrine and neuroimmune systems (50). The mutual functional relationship between the nervous, endocrine, and immune systems is now well established, and they probably form the anatomical, physiological and cellular bases explaining why and how life events may modulate intestinal immune responses in health and disease (51). It is far too premature to define complete pathways and postulate hypotheses for IBD. Nevertheless, this area of investigation is beginning to be vigorously pursued, and may yield information of scientific and practical value in the near future.

\section{POSSIBLE MECHANISMS OF TISSUE DAMAGE IN IBD}

In any disease the study of the mechanisms of tissue damage holds the key to treatment, as drugs or other measures can be devised to block neutralize or inhibit active agents revert the pathological process, and restore normality. Thus, to understand what mechanisms are crucial to gut tis. sue damage is obviously of fundamental importance in IBD. For practical purposes, the candidate mechanisms can 


\begin{tabular}{|c|c|}
\hline Immune & Nonimmune \\
\hline Activated T cells & Neutrophils \\
\hline Antibodies & $\begin{array}{l}\text { Free oxygen } \\
\text { radicals }\end{array}$ \\
\hline Complement & Leukotrienes \\
\hline Macrophages & Thromboxanes \\
\hline Mast cells & $\begin{array}{l}\text { Other soluble } \\
\text { mediators }\end{array}$ \\
\hline
\end{tabular}

be divided into immune and nonimmune, as delineated in Table 5. Unfortunately the list is long in both categories, and it is uncertain how many and which ones are the most important and should be the target of therapeutic approaches.

As already indicated, autoimmune phenomena and abnormalities of intestinal immunity are likely contributors to intestinal inflammation in Crohn's disease and ulcerative colitis. However, the capacity for modulating the immune system is limited at present, being restricted to the use of drugs with variable degrees of specificity for the different mononuclear cell subsets (52). Upon activation these cells produce a variety of soluble mediators, most of which are well defined functionally and biologically (53). These biological activities are broad and extremely potent, making cytokines very pertinent to and directly responsible for many of the pathological manifestations of tissue damage. A dramatic example of their action and the beneficial result of their modulation has been recently described in an animal model. In mice undergoing graft-versus-host disease the severe intestinal involvement and related mortality was almost entirely abolished by administration of antibodies to tumour necrosis factor (54). Therefore, there is little doubt that activated mononuclear cell-derived soluble factors can amplify and maintain intestinal inflammation (55). This strongly justifies the intense study of cytokines which is currently being pursued in IBD, by measuring their levels in the inflamed mucosa (Table 6), as well as assessing their effect on the local immune cells (56).

TABLE 6

Cytokine activities in the intestinal mucosa of inflammatory bowel disease"

\begin{tabular}{|c|c|c|}
\hline \multirow[b]{2}{*}{ Cytokine } & \multicolumn{2}{|c|}{ Experimental conditions } \\
\hline & Unstimulated & Stimulated \\
\hline Interleukin-1 & Increased & Increased \\
\hline Interleukin-2 & Undetectable & Decreased \\
\hline Interferon-y & Undetectable & Deecreased \\
\hline Colony stimulating factor & Increased & Increased \\
\hline Interleukin-4 & $?$ & $?$ \\
\hline Interleukin-5 & ? & $?$ \\
\hline Interleukin-6 & Increased & ? \\
\hline Interleukin-7 & $?$ & $?$ \\
\hline Interleukin-8 & Increased & $?$ \\
\hline Tumour necrosis factor- $\alpha$ & $\begin{array}{l}\text { Comparable/ } \\
\text { undetectable }\end{array}$ & $?$ \\
\hline Tumour necrosis factor- $\beta$ & $?$ & ? \\
\hline Platelet activating factor & Increased & Increased \\
\hline Transforming growth factor- $\alpha$ & Increased $^{\dagger}$ & $?$ \\
\hline Transforming growth factor $-\beta$ & Comparable & ? \\
\hline
\end{tabular}

"Levels in organ culture, cell culture, cell extract or mRNA compared to levels from histologically normal control intestinal mucosa. ${ }^{\dagger}$ In inactive ulcerative colitis

Nonimmune factors are also present and obviously active in inflamed intestinal tissue. Prostaglandins have received much attention as 'proinflammatory' substances, but more recently their action is believed to be more of a cytoprotective nature, whereas thromboxanes and especially leukotrienes are currently held as responsible for tissue destruction and inflammation, as discussed elsewhere. More and more attention is being devoted to the investigation of the increasingly important role of polymorphonuclear neutrophils in tissue damage (57). Neutrophils are abundant in active lesions of both human IBD and experimental animal colitis, and one of their actions is the generation of oxygen free radicals, which is also discussed elsewhere. It is quite possible that during inflammation additional unidentified substances are released that possess tissue-damaging potential.

Gastroenterologists and surgeons, forced to deal with the reality of the clinical manifestations of IBD but lacking basic knowledge of its cause, have obtained a reasonable degree of success in treating patients affected by Crohn's disease and ulcerative colitis. In some skeptical minds, the need for basic information about the nature of these diseases may even seem irrelevant to practical treatment. Nevertheless, both practising clinicians and basic investigators have the obligation to share knowledge and experience, trying to help and complement each other. The process of incorporating basic knowledge into clinical therapy is always painstaking and slow, but during the past decade enough new data on gut immunology and inflammatory mediators have been gathered that future therapeutic intervention for IBD may derive from this newly acquired body of information. In the following paragraphs, an attempt will be made to show how this may be so.

In relation to the temporal ap. pearance of clinical manifestations, treatment of IBD can be classified as early or late. Early treatment implies the actual prevention of disease, or its detection before florid clinical manifestations become evident. To do so it is imperative to detect or measure parameters that reflect an enhanced susceptibility to IBD or a higher than normal chance of acquiring the disease. Unfortunately, no 'markers' are available, although some candidates are under investigation (Table 7).

The continued study of immunogenetics is exploring new single genes or a combination of them which may show a consistent association with Crohn's disease or ulcerative colitis, as detailed elsewhere. The recently 


\section{TABLE 7 \\ Potential markers of inflammatory bowel disease}

Histocompatibility antigens

Reactivity to epithelial cell-associated

Antineutrophil cytoplasmic antibody Intestinal mucin abnormality Increased intestinal permeability High risk environment components

TABLE 8

Therapeutic interventions in inflamamtory bowel disease

\begin{tabular}{lc}
\hline Current & Future \\
\hline Aminosalicylates & Soluble mediator blockade: \\
Corticosteroids & Inhibitors \\
Immunosuppressives & Antagonists \\
Antibiotics & Receptor blockade \\
Diet & (Leukotrienes, thromboxanes, etc) \\
& Immune mediator blockade \\
(ILI, IL6, TNF, PAF, etc) \\
Oxygen radical scavengers \\
Antibiotics
\end{tabular}

IL Interleukin: INF Tumour necrosis factor: PAF Platelet activating factor

described high frequency of serum antibodies to epithelial cell-associated components in healthy relatives of IBD patients may indicate a shared genetic predisposition or exposure to a common environmental agent (58). A similar situation may exist for the recently described antinuclear cytoplasmic antibodies preferentially found in ulcerative colitis (42). Further studies of intestinal mucin abnormalities may show an intriguing association with ulcerative colitis (59), while increased intestinal permeability may be holding clues to the development of Crohn's disease (60). The existence of a well defined high risk environment may suffice to predict a higher than normal occurrence of IBD.

Late treatment is essentially the only one now practised, and involves the suppression of inflammation and relief of clinical symptoms. Current drugs include salicylates, cortico-

\section{REFERENCES}

1. Jenkins D, Goodall A, Scott BB. Ulcerative colitis: One disease or two? (Quantitative histological differences between distal and extensive disease). Gut 1990;31:426-30.

2. Walvoort HC, Pena AS. Crohn's disease: Entity and aetiopathogenic concepts. J Clin Nutr Gastroenterol 1987;2:194-200,

3. Bargen JA. Experimental studies on the etiology of chronic ulcerative colitis. JAMA 1924;83:332-6.

4. Parent K, Mitchell P. Cell wall-defective variants of Pseudomanas-like (group Va) bacteria in Crohn's disease. Gastroenterology 1978;75:368-72.

5. Mitchell DN, Rees RJ. Agent transmissible from Crohn's disease tissue. Lancet 1970;ii:168-71.

6. Gitnick GL, Arthur MH, Shibata I. Cultivation of viral agents from Crohn's disease. Lancet 1976;ii:215-7. steroids, immunosuppressives and antibiotics (52). However, many recent and ongoing studies of IBD pathogenesis hold new hopes for a totally new array of weapons in the therapeutic arsenal against Crohn's disease and ulcerative colitis (Table 8). While the initiation and perpetuation of intestinal inflammation is undoubtedly very intricate, it is also likely that most mechanisms of tissue destruction act through a relatively restricted number of mediators represented by immune and nonimmune soluble factors. Advances in biochemistry, cell biology molecular biology, and pharmacology have helped in devising means of controlling the action of substances such as leukotrienes or thromboxanes by generating highly specific antagonists, inhibitors or receptor blockers. The

7. Das KM, Valenzuela I, Morecki R. Crohn's disease lymph node homogenates produce murine lymphoma in athymic mice. Proc Natl Acad Sci USA 1980;77:588-92.

8. McLaren LC, Gitnick G. Ulcerative colitis and Crohn's disease tissue cytotoxins. Gastroenterology 1982;82:1381-8.

9. Collins JF, Strickland RG, Kekahbah EL, Arthur MH, Naeim F, Gitnick GL. Histological response and antigen transmission in the lymph nodes of athymic nu/nu mice inoculated with Crohn's disease tissue filtrates. Gut 1988:29:983-9.

10. Walvoort HC, Fazzi GE, Pena AS. Seroreactivity of patients with Crohn's disease with lymph nodes of primed nude mice is independent of the tissue used for priming. Gastroenterology 1989;97:1097-100.

11. Chiodini RJ, Kruiningen HJV, Thayer same is true for several of the proinflammatory cytokines, including interleukin-1, interleukin-6, tumour necrosis factor, platelet activating fac tor, etc. In vitro and in vivo experiments using these strategies are actually being conducted in several laboratories. With the realization of the potent tissue damaging potential of oxygen-derived free radicals, oxygen radical scavengers are being screened in animal models and clinical trials. One of the actions of 5-aminosalicylic acid, the active principle of sulphasalazine and one of the most effective drugs for the treatment of IBD, appears to be through its oxygen radical scavenger activity (61). New antibiotics are constantly being generated that may prove efficacious in some cases with an infectious cause or complication.

WR, Merkal RS, Coutu JA. Possible role of mycobacteria in inflammatory bowel disease. I. An unclassified Mycobacterium species isolated from patients with Crohn's disease. Dig Dis Sci 1984;29:1073-9.

12. Chiodini RJ. Crohn's disease and the mycobacterioses: A review and comparison of two disease entities. Clin Microbiol Rev 1989;2:90-117.

13. Graham DY, Markesich DC, Yoshimura HH. Mycobacteria and inflammatory bowel disease. Results of culture. Gastroenterology 1987;92:436 42.

14. Kobayashi K, Blaser MJ, Brown WR. Immunohistochemical examination for mycobacteria in intestinal tissues from patients with Crohn's disease. Gastroenterology 1989;96:1009-15.

15. Butcher PD, McFadden JJ, HermonTaylor J. Investigation of mycobacteria in Crohn's disease tissue by Southern 
blotting and DNA hybridization with cloned mycobacterial genomic DNA probes from a Crohn's disease isolated mycobacteria. Gut 1988;29:1222-8.

16. Kobayashi K, Brown WR, Brennan PL, Blaser MJ. Serum antibodies to mycobacterial antigens in active Crohn's disease. Gastroenterology 1988;94:1404-11.

17. Seldenrijk CA, Drexhage HA, Meuwissen SGM, Meijer CJLM. T-cellular immune reactions (in macrophage inhibitor factor assay) against Mycobacterium paratuberculosis, Myobacterium kansasii, Myobacterium tuberculosis, Myobacterium avium in patients with chronic inflammatory bowel disease. Gut 1990;31:529-35.

18. Volk BA, Niessner M, Kaufmann SHE, Fauser AA, Gerok W. Mycobacteria-reactive subset of $\gamma / \delta$ lymphocytes from human gut biopsies. Gastroenterology 1990;98:477. (Abst)

19. Janis EM, Kaufmann SHE, Schwartz RH, Pardoll DM. Activation of $\gamma \delta \mathrm{T}$ cells in the primary immune response to Mycobacterium tuberculosis. Science 1989;244:713-6.

20. Kaufmann SHE. Heat shock proteins and the immune response. Immunol Today 1990;11:129-36.

21. Polla BS. A role for heat shock proteins in inflammation? Immunol Today 1988;9:134-7.

22. Elson $\mathrm{CO}$. Endotoxin and the mucosal immune response. In: Strober W, Hanson LA, Sell KW, eds. Recent Advances in Mucosal Immunity. New York: Raven Press 1982:73-80.

23. Lagercrantz R, Hammarstrom S, Perlmann P, Gustafsson BE. Immunological studies in ulcerative colitis. IV. Origin of autoantibodies. J Exp Med 1968;128:1339-52.

24. Thayer WR, Brown M, Sangree MH, Katz ], Hersh T. Escherichia coli 0:14 and colon hemagglutinating antibodies in inflammatory bowel disease. Gastroenterology 1969;57:311-8.

25. Bull DM, Ignaczk TF. Enterobacterial common antigen-induced lymphocyte reactivity in inflammatory bowel disease. Gastroenterology 1973;64:4350.

26. Sartor RB, Cromartie WJ, Powell DW, Schwab JH. Granulomatous enterocolitis induced in rats by purified bacterial cell wall fragments.

Gastroenterology 1985;89:587-95.

27. LeDuc LE, Nast CC. Chemotactic peptide-induced acute colitis in rabbits. Gastroenterology 1990;98:929-35.

28. Kirsner JB, Spencer JA. Family occurrence of ulcerative colitis, regional enteritis and ileocolitis. Ann Intern Med 1963;59:133-44.

29. Farmer RG, Michener WM. Associa- tion of inflammatory bowel disease in families. Front Gastrointest Res 1986;11:17-26.

30. Lewkonia RM, McConnel RB. Familial inflammatory bowel disease heredity or environment? Gut 1976;17:235-41.

31. Asakura H, Tsuchiya M, Aiso S, et al. Association of the human lymphocyteDR2 antigen with Japanese ulcerative colitis. Gastroenterology 1982;82:413-8.

32. Volk BA, Howell MD, Smith J, Kagnoff MF. Association of $\alpha$ polymeric human $\mathrm{T}$-cell receptor achain fragment with ulcerative colitis. Gastroenterology 1988;94:482. (Abst)

33. Randolph LM, Toyoda $H$, McElree CK, Shanahan F, Targan SR, Rotter JI. Lack of an association between polymorphisms of the $T$-cell receptor $\alpha$-chain and ulcerative colitis. Gastroenterology 1989;97:1115-20.

34. Fiocchi C, Farmer RG. Autoimmunity in inflammatory bowel disease. Clin Asp Autoimmun 1987;1:12-9.

35. Oldstone MBA. Molecular mimicry and autoimmune disease. Cell 1987;50:819-20.

36. Kagnoff MA, Austin RK, Hubert JJ, Bernardini JE, Kasarda DD. Possible role for a human adenovirus in the pathogenesis of celiac disease. J Exp Med 1984;160:1544-57.

37. Schwimmbeck PL, Yu DTY, Oldstone MBA. Autoantibodies to HLA B27 in the sera of HLA B27 patients with ankylosing spondylitis and Reiter's syndrome. J Exp Med 1987;166:173-81.

38. Bendixen G. Specific inhibition of the in vitro migration of leukocytes in ulcerative colitis and Crohn's disease. Scand J Gastroenterol 1967;2:214-21.

39. Mayer H, Schmidt G. Chemistry and biology of the enterobacterial common antigen (ECA). In: Current Topics in Microbiology and Immunology. New York: Springer-Verlag 1979:99-153.

40. Roche JK, Fiocchi C, Youngman K. Sensitization to epithelial antigens in chronic mucosal inflammatory disease. Characterization of human intestinal mucosa-derived mononuclear cells reactive with purified epithelial cellassociated components in vitro. J Clin Invest 1985;75:522-30.

41. Das KM, Vecchi M, Sakamaki S. A shared and unique epitope(s) on human colon, skin, and biliary epithelium detected by a monoclonal antibody. Gastroenterology 1990;98:464-9.

42. Targan S, Saxon A, Landers C, Ganz $T$, Shanahan F. Serum antineutrophil anti-cytoplasmic antibodies distinguish ulcerative colitis from Crohn's disease. Gastroenterology 1989;96:505. (Abst)

43. MacDermott RP, Stenson WF. Alterations of the immune system in ulcerative colitis and Crohn's disease. Adv Immunol 1988;42:285-328.

44. Fiocchi C. Mucosal immunity and inflammation. Ital ] Gastroenterol 1989;21:81-90.

45. Kusugami K, Youngman KR, West $\mathrm{GA}$, Fiocchi C. Intestinal immune reactivity to interleukin 2 differs among Crohn's disease, ulcerative colitis and control. Gastroenterology 1989;97:1-9.

46. MacDermott RP, Nash GS, Bertovich MJ, Seiden MV, Bragdon MJ, Beale MG. Alterations of $\operatorname{IgM}, \lg G$, and $\operatorname{Ig} A$ synthesis and secretion by peripheral blood and intestinal mononuclear cells from patients with ulcerative colitis and Crohn's disease. Gastroenterology 1981;81:844-52.

47. Fiocchi C, Hilfiker ML, Youngman KR, Doerder NC, Finke JH. Interleukin 2 activity of human intestinal mucosal mononuclear cells. Decreased levels in inflammatory bowel disease. Gastroenterology 1984;86:734-42.

48. Yen-Lieberman B, Fiocchi C, Youngman KR, Sapatnekar WK, Proffitt MR. Interferon $\gamma$ production by human intestinal mucosal mononuclear cells. Decreased levels in inflammatory bowel disease. Dig Dis Sci 1988;33:1528-36.

49. Halstensen TS, Molines TE, Garred P, Fausa O, Brandtzaeg P. Epithelial deposition of immunoglobulin G1 and activated complement ( $\mathrm{C} 3 \mathrm{~b}$ and terminal complement complex) in ulcerative colitis. Gastroenterology 1990;98:1264-71

50. Khansari DN, Murgo AJ, Faith RE. Effects of stress on the immune system. Immunol Today 1990;11:170-5.

51. O'Dorisio MS. Neuropeptides and gastrointestinal immunity. Am J Med 1986;81(Suppl 6B):74-82.

52. Hawthorne AB, Hawkey CJ. Immunosuppressive drugs in inflammatory bowel disease. A review of their mechanisms of efficacy and place in therapy. Drugs 1989;38:267-88.

53. Mizel SB. The interleukins. FASEB J 1989;3:2379-88.

54. Piguet P-F, Grau GE, Allet B, Vassaili $P$. Tumor necrosis factor-cachectin is an effector of skin and gut lesions of the acute phase of graft-vs-host disease. J Exp Med 1987;166:1290-9.

55. Fiocchi C. Lymphokines and the intestinal immune response. Role in inflam. matory bowel disease. Immunol lnvest 1989;18:91-102.

56. Fiocchi C, Matsuura T, Levine AD, West GA, Youngman KR. Mucosal cytokines and immunocytotoxicity in inflammatory bowel disease. Proceedings from the Sixth International Congress of Mucosal Immunology 1990. (In press) 
57. Weiss SJ. Tissue destruction by neutrophils. N Engl J Med 1989;320:365-76.

58. Fiocchi C, Roche JK, Michener WM. High prevalence of antibodies to intestinal epithelial antigens in patients with inflammatory bowel disease and their relatives. Ann Intern Med 1989;110:786-94.

59. Rhodes JM. Colonic mucus and mucosal glycoproteins: The key to colitis and cancer? Gut 1989;30:1660-6.

60. Hollander D. Crohn's disease - A permeability disorder of the tight junc- tion? Gut 1988;29:1621-4.

61. Ahnfelt-Ronne I, Nielsen OH,

Christensen A, Langholz E, Binder V, Riis P. Clinical evidence supporting the radical scavenger mechanism of 5-aminosalicylic acid. Gastroenterology 1990;98:1162-9. 


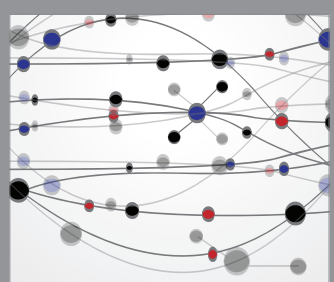

The Scientific World Journal
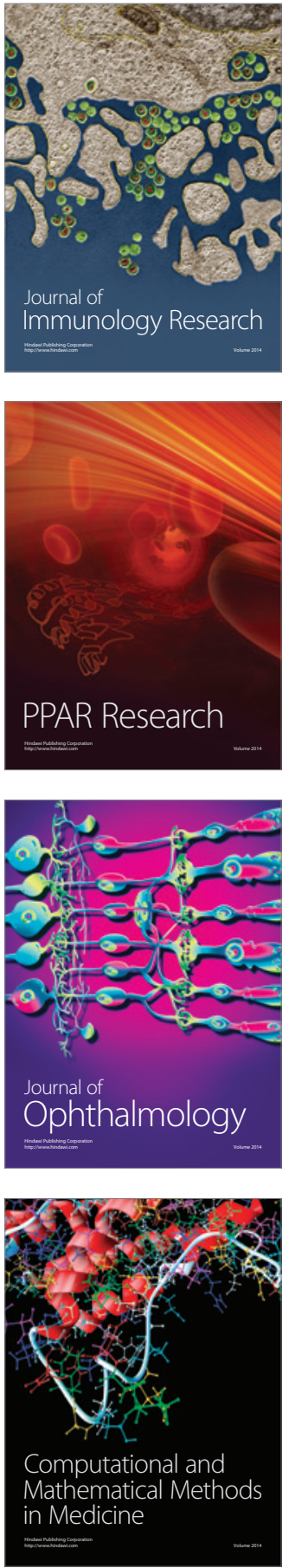

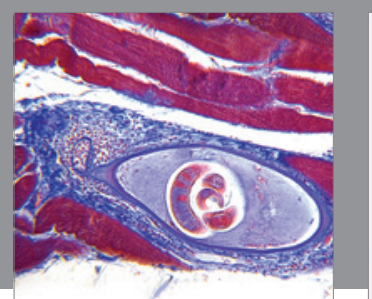

Gastroenterology Research and Practice

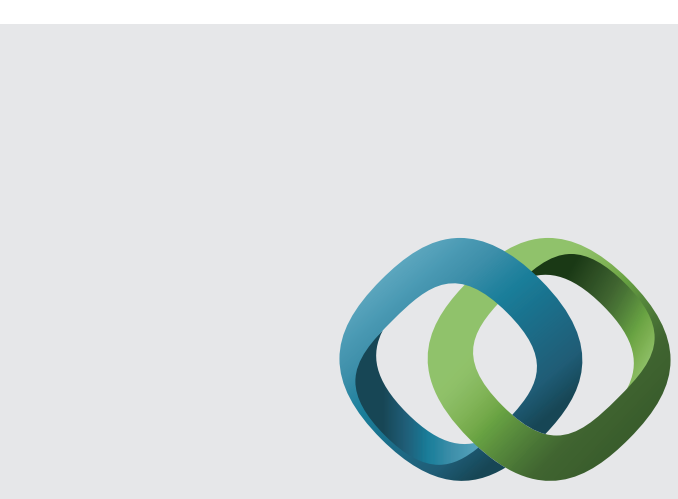

\section{Hindawi}

Submit your manuscripts at

http://www.hindawi.com
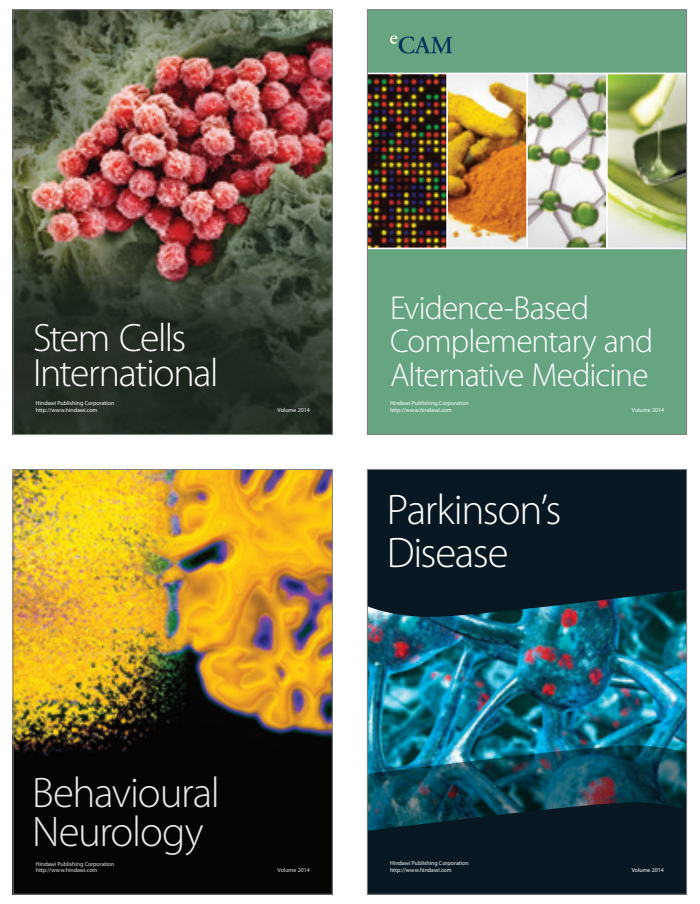
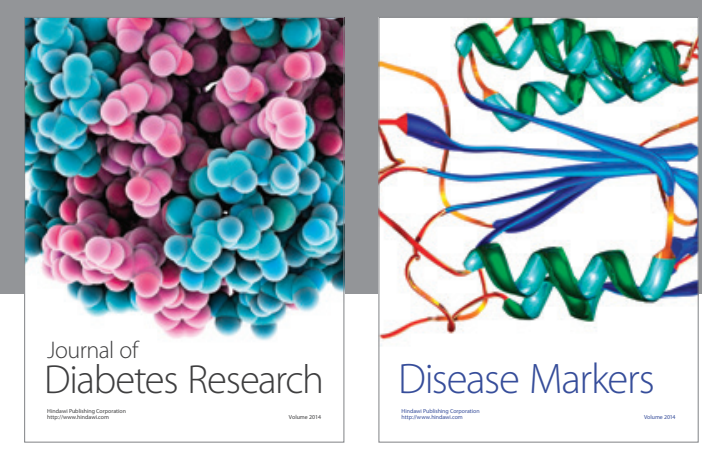

Disease Markers
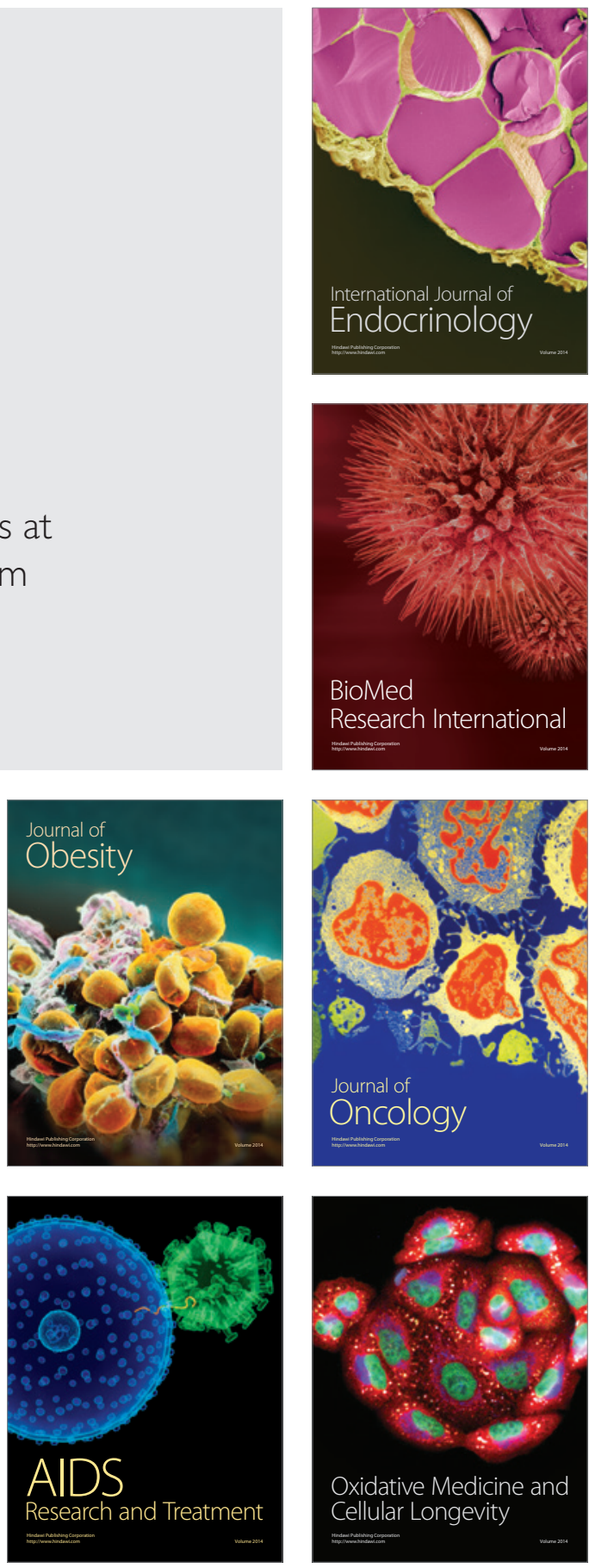